\title{
Reducing enteric methane emissions from dairy cattle: Two ways to supplement 3-nitrooxypropanol
}

\author{
D. Van Wesemael, ${ }^{1,2}$ L. Vandaele, ${ }^{1}$ B. Ampe, ${ }^{1}$ H. Cattrysse, ${ }^{1}$ S. Duval, ${ }^{3}$ M. Kindermann, ${ }^{3}$ V. Fievez, ${ }^{2}$ \\ S. De Campeneere, ${ }^{1}$ and N. Peiren ${ }^{1 *}$ \\ ${ }^{1}$ Animal Sciences Unit, Flanders Research Institute for Agriculture, Fisheries and Food, Scheldeweg 68, 9090 Melle, Belgium \\ ${ }^{2}$ Department of Animal Sciences and Aquatic Ecology, Laboratory for Animal Nutrition and Animal Product Quality, Ghent University, \\ Coupure Links 653 Block F, 9000 Ghent, Belgium \\ ${ }^{3}$ DNP Innovation Animal Nutrition \& Health, DSM Nutritional Products, PO Box 2676, 4002 Basel, Switzerland
}

\section{ABSTRACT}

The aim of this work was to determine the effect of 3-nitrooxypropanol (3-NOP) on the enteric methane $\left(\mathrm{CH}_{4}\right)$ emissions and performance of lactating dairy cows when mixed in with roughage or incorporated into a concentrate pellet. After 2 pretreatment weeks without 3-NOP supplementation, 30 Holstein Friesian cows were divided into 3 homogeneous treatment groups: no additive, 3-NOP mixed in with the basal diet (roughage; $\mathrm{NOP}_{\mathrm{bas}}$ ), and 3 -NOP incorporated into a concentrate pellet $\left(\mathrm{NOP}_{\text {conc }}\right)$. The pretreatment period was followed by a 10-wk treatment period in which the $\mathrm{NOP}_{\text {bas }}$ and $\mathrm{NOP}_{\text {conc }}$ cows were fed $1.6 \mathrm{~g}$ of $3-\mathrm{NOP} / \mathrm{cow}$ per day. After the treatment period, a 2-wk washout period followed without 3-NOP supplementation. The $\mathrm{CH}_{4}$ emissions were measured using a GreenFeed unit (C-Lock Inc., Rapid City, SD) installed in a freestall with cubicles during the entire experimental period. On average for the total treatment period and compared with the no-additive group, $\mathrm{CH}_{4}$ production $(\mathrm{g} / \mathrm{d})$ was 28 and $23 \%$ lower for $\mathrm{NOP}_{\text {bas }}$ and $\mathrm{NOP}_{\text {conc }}$, respectively. Methane yield $(\mathrm{g} / \mathrm{kg}$ of dry matter intake) and methane intensity (g/kg of milk) were 23 and $24 \%$ lower for $\mathrm{NOP}_{\text {bas }}$, respectively, and 21 and $22 \%$ lower for $\mathrm{NOP}_{\text {conc }}$, respectively. No differences were found between $\mathrm{NOP}_{\text {bas }}$ and $\mathrm{NOP}_{\text {conc }}$. Moreover, supplying 3-NOP did not affect total dry matter intake, milk production, or milk composition. The results of this experiment show that 3 -NOP can reduce enteric $\mathrm{CH}_{4}$ emissions of dairy cattle when incorporated into a concentrate pellet and that this reduction is not different from the effect of mixing in 3-NOP with the basal diet (roughage). This broadens the possibilities for using 3-NOP in the dairy sector worldwide, as it is not always feasible to provide an additive mixed in with the basal diet.

Received February 2, 2018.

Accepted October 3, 2018.

*Corresponding author: nico.peiren@ilvo.vlaanderen.be
Key words: 3-nitrooxypropanol, dairy cow, methane, greenhouse gas emission reduction

\section{INTRODUCTION}

In an attempt to reduce enteric methane $\left(\mathrm{CH}_{4}\right)$, the main greenhouse gas from livestock, Duval and Kindermann (2012) developed the feed additive 3-nitrooxypropanol (3-NOP). When added to a ruminant diet, this additive blocks the last step of methanogenesis in the rumen by oxidizing the enzyme methyl-coenzyme M reductase (Duin et al., 2016). This enzyme is responsible for the reduction of methyl-coenzyme $\mathrm{M}$ with coenzyme $\mathrm{B}$ to $\mathrm{CH}_{4}$ and a coenzyme-M-coenzyme- $\mathrm{B}$ complex (Ermler et al., 1997). Although 3-NOP is relatively new, many in vivo experiments with this additive have already been conducted with beef cattle (e.g., Romero-Perez et al., 2015; Vyas et al., 2016a,b), dairy cattle (e.g., Reynolds et al., 2014; Hristov et al., 2015; Haisan et al., 2017), and sheep (Martínez-Fernández et al., 2014). For dairy cattle, reported mitigation percentages have ranged from $7 \%$ (Reynolds et al., 2014) to $60 \%$ (Haisan et al., 2014). The lower mitigation in Reynolds et al. (2014) was presumed to originate from the way it was supplied to the cows: 2 times per day directly into the rumen at feeding time. In most other studies, the additive was mixed into the TMR, and reduction percentages between 23\% (Haisan et al., 2017) and $34 \%$ (Lopes et al., 2016) were found. Hristov et al. (2015) and Romero-Perez et al. (2015) suggested that the potential of 3-NOP for lowering enteric $\mathrm{CH}_{4}$ emissions was dependent on the method of supplementation. They hypothesized that provision of 3-NOP in a TMR is the most effective way, possibly because the additive is ingested more frequently throughout the day, leading to a more continuous presence in the rumen (Hristov et al., 2015).

On dairy cattle farms in Western Europe, it is far more common to supplement a basal roughage diet with separate concentrate feeding rather than feeding 


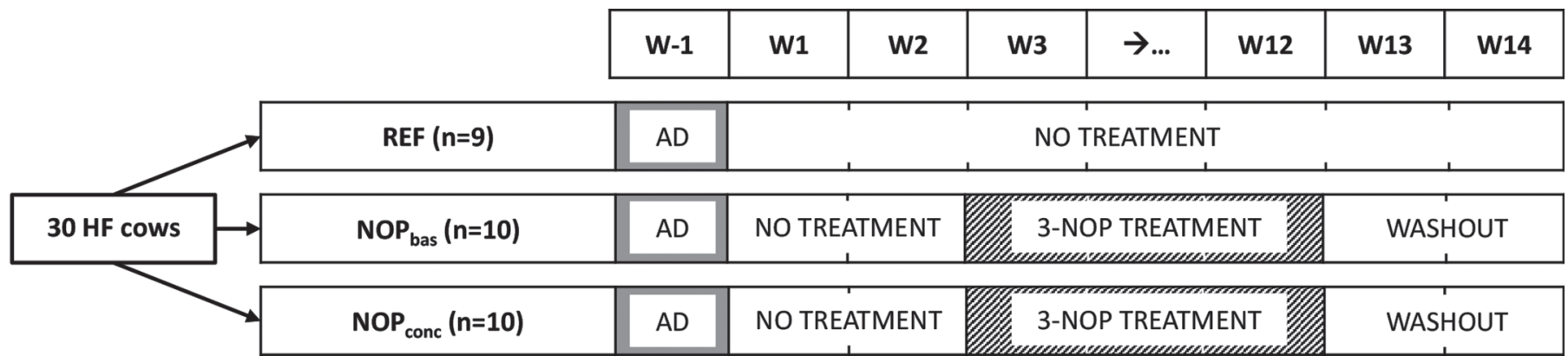

Figure 1. Scheme of the experimental setup. The cows in $\mathrm{NOP}_{\text {bas }}$ received 3-nitrooxypropanol (3-NOP) mixed in with the roughage (1.6 g/ cow per day), the cows in NOP ${ }_{\text {conc }}$ received 3-NOP incorporated in a concentrate pellet (1.6 g/cow per day), and the reference group (REF) never received 3-NOP. HF = Holstein Friesian; AD = adaptation; $\mathrm{W}=$ week.

a TMR. Most dairy farmers use concentrate feed stations, in parlor as well as out of parlor, to feed the individual animals in accordance with their dietary needs (e.g., milk production and stage of lactation). To date, no in vivo experiment with 3 -NOP has assessed the methane mitigation potential of the additive when it is provided in a concentrate. The present study examined this knowledge gap as a next step to commercialization of the product in the Western European dairy sector. Therefore, we performed an experiment in which 3-NOP was incorporated into a pelleted compound feed and fed to lactating dairy cows for $10 \mathrm{wk}$ in an out-of-parlor concentrate feed station. The effect of the 3-NOP pelleted compound feed was compared with supplementation of 3-NOP mixed in with the roughage. A third group of cows did not receive the additive (reference group). We hypothesized that this new way of supplementing 3-NOP would be effective too, along with 3-NOP mixed in with the roughage, provided the compound feed is ingested frequently throughout the day.

\section{MATERIALS AND METHODS}

The experiment was carried out at the experimental farm of ILVO (Flanders Research Institute for Agriculture, Fisheries and Food, Melle, Belgium) during summer and autumn of 2016. All animal handling and sampling procedures were approved by the ILVO Animal Ethics Committee (EC 2016/279).

\section{Experimental Design and Treatments}

The experiment started with an adaptation week (without data collection), followed by a pretreatment period of 2 wk (Figure 1) in which all cows $(\mathrm{n}=30$; average \pm SD: $121 \pm 59$ DIM, $32.1 \pm 4.8 \mathrm{~kg}$ of milk/d) received the roughage-based diet described in Table 1 . After this pretreatment period, the animals were di- vided into 3 homogeneous treatment groups of 10 cows using a balanced randomization procedure based on parity, milk production $(\mathrm{kg} / \mathrm{d})$, DIM, BW $(\mathrm{kg})$, milk fat (\%), milk protein (\%), roughage DMI $(\mathrm{kg} / \mathrm{d})$, roughage DMI:total DMI ratio $(\mathrm{kg} / \mathrm{kg})$, and $\mathrm{CH}_{4}$ emissions $(\mathrm{g} / \mathrm{d})$ during the pretreatment period. Each group was randomly assigned to 1 of 3 treatments: no 3-NOP (REF), 3-NOP (DSM Nutritional Products, Basel, Switzerland) mixed in with the basal diet (roughage; $\mathbf{N O P}_{\text {bas }}$ ), and 3 -NOP incorporated in a pelleted balanced compound feed provided in an out-of-parlor concentrate feeder $\left(\mathbf{N O P}_{\text {conc }}\right)$. In the final period of $2 \mathrm{wk}$ (washout), none of the groups received 3-NOP supplementation.

All cows were housed in a freestall with cubicles and had at all times access to the roughage mixture through Roughage Intake Control feed bins (Hokofarm Group BV, Marknesse, the Netherlands). Concentrates were provided via standard in-parlor and out-of-parlor feed stations (DeLaval NV, Drongen, Belgium), and a GreenFeed (C-Lock Inc., Rapid City, SD) concentrate dispenser. The additive $(80 \mathrm{~g} / \mathrm{kg})$ was mixed with soybean meal $(875 \mathrm{~g} / \mathrm{kg})$ and soybean oil $(45 \mathrm{~g} / \mathrm{kg})$ either before it was mixed in with the roughage or before it was combined with the compound feed ingredients to make the pellets. The pelleting was done with a Promill press (type 1003; Promill, Serville, France) that does not use steam in the pelleting process. The expected maximum temperature during the process was around 60 to $70^{\circ} \mathrm{C}$. The additive was given at a dose of $1.6 \mathrm{~g} /$ cow per day or $100 \mathrm{mg} / \mathrm{kg}$ roughage DM, with an average roughage DMI of $16 \mathrm{~kg}$ at the start of the trial. For $\mathrm{NOP}_{\text {bas }}$, ad libitum roughage intake determined the intake of 3-NOP, whereas for $\mathrm{NOP}_{\text {conc }}$, the 3 -NOP intake needed to be adjusted each week based on the previous week's roughage intake by changing the amount of the 3 -NOP compound feed (1 kg contains $1.6 \mathrm{~g}$ of 3 -NOP). The REF and $\mathrm{NOP}_{\text {conc }}$ groups received a mixture of soybean meal $(951 \mathrm{~g} / \mathrm{kg})$ and soybean oil $(49 \mathrm{~g} / \mathrm{kg})$ mixed in with the roughage. 
Table 1. Ingredients and chemical composition $(\mathrm{g} / \mathrm{kg}$ of DM unless noted) of the experimental diet

\begin{tabular}{lr}
\hline Item & Value \\
\hline Ingredient & \\
Maize silage & 351 \\
Grass silage & 307 \\
Pressed beet pulp & 73 \\
Urea mix & 6 \\
Straw & 4 \\
Balanced compound feed & 180 \\
Starchy balanced compound feed & 40 \\
Formaldehyde-treated soybean meal & 6 \\
Soybean meal & 25 \\
Soybean meal-soybean oil mixture & 8 \\
Chemical composition & \\
DM (g/kg) & 411 \\
CP & 157 \\
Ether extract & 29 \\
Crude fiber & 182 \\
NDF & 346 \\
ADF & 203 \\
ADL & 18 \\
Starch & 176 \\
Sugars & 39 \\
VEM & \\
DVE & 985 \\
OEB & 83 \\
Fermentable OM & \\
&
\end{tabular}

${ }^{1} 880 \mathrm{~g} / \mathrm{kg}$ of urea and $120 \mathrm{~g} / \mathrm{kg}$ of wheat (fresh matter).

${ }^{2} \mathrm{VEM}=$ feed unit lactaction (Van Es, 1978).

${ }^{3} \mathrm{DVE}=$ true protein digested in the small intestine.

${ }^{4}$ Tamminga et al. (1994).

${ }^{5} \mathrm{OEB}=$ degraded protein balance.

One cow from the REF group left the experiment due to lameness, and all collected data (emission and performance data) from this cow were omitted. In the final week of the treatment period (wk 12), 12 cows (4 cows/treatment) were moved to tiestalls for total urine and feces collection to determine the treatment effect on nitrogen metabolism (data not shown). Data from this week are not taken into account for any of the cows. In addition, all data from wk 3 had to be omitted due to technical problems. Week 4 was therefore the first week of treatment.

\section{Measurements and Sampling}

Individual daily $\mathrm{CH}_{4}$ and $\mathrm{CO}_{2}$ emissions were measured during the entire experimental period when the cows visited the GreenFeed unit (Huhtanen et al., 2015). The cows were allowed to visit the GreenFeed unit every $4 \mathrm{~h}$ (maximum of 6 times/d), but data collection was dependent on the cows' voluntary visits to the GreenFeed unit. Typically, short (3-7 min) measurements are needed several times per day for several consecutive days to define the daily emissions of a cow (Hammond et al., 2015). Every cow needed a minimum number $(\geq 15 / \mathrm{wk})$ of accurate visits to the GreenFeed unit before the data could be used to calculate the average value for the group. Despite our best efforts to train all the cows to visit the GreenFeed unit, some (older) cows either did not visit it frequently or held their heads in a bad position. Based on the minimum required number of accurate visits to the GreenFeed unit per week, some cows were excluded in some of the experimental weeks (average number of visits of the excluded animals per week: $10.1 \pm 0.47$ ). This led to weekly variation in the number of animals used to calculate the weekly group average. For REF, $\mathrm{CH}_{4}$ data of a minimum of 6 out of 9 cows were included (average number of visits per week: $24.3 \pm 0.48$ ); for $\mathrm{NOP}_{\text {bas }}$ this was 8 out of 10 (average number of visits per week: 26.3 \pm 0.56 ), and for $\mathrm{NOP}_{\text {conc }}$ this was 6 out of 10 (average number of visits per week: $24.4 \pm 0.57$ ).

Milk samples were taken during 4 consecutive milkings every 2 wk starting from wk 2 (last week of the pretreatment period) onward, with additional sampling in the first week. Samples were analyzed for milk fat, milk protein, and MUN using Fourier-transform infrared spectroscopy (LactoScope FTIR Advanced, Delta Instruments, Drachten, the Netherlands). Milk production was corrected for fat and protein content by calculating fat- and protein-corrected milk (FPCM) production with the formula

$$
\begin{gathered}
\mathrm{FPCM}=[0.337+(0.116 \times \% \text { fat }) \\
+(0.06 \times \% \text { protein })] \times \text { milk production } .
\end{gathered}
$$

Milk composition for the weeks without samples was calculated from the measurements in the previous and the following week in the same period. In this way, no milk composition could be calculated for wk 11 and 13 . Feed samples were taken every 2 wk and were analyzed for DM, chemical composition, and rumen degradability as described by De Boever et al. (2017).

\section{Statistics}

All outcome variables were averaged for each cow and each measurement week of the pretreatment, treatment, and washout periods. Data were analyzed by using a linear mixed model:

$$
\mathrm{Y}_{\mathrm{ij}}=\mu+\mathrm{G}_{\mathrm{i}}+\mathrm{W}_{\mathrm{j}}+\mathrm{G}_{\mathrm{i}} \times \mathrm{W}_{\mathrm{j}}+\mathrm{C}_{\mathrm{i}}+\varepsilon_{\mathrm{ij}},
$$

where $Y_{i j}$ is the dependent variable for cow $i$ during week $j, \mu$ is the overall mean, $G_{i}$ is the fixed effect of group (REF, NOP ${ }_{\text {bas }}$, and $\mathrm{NOP}_{\text {conc }}$ ), $\mathrm{W}_{\mathrm{j}}$ is the fixed effect of week, $G_{i} \times W_{j}$ is the group $\times$ week interaction, $\mathrm{C}_{\mathrm{i}}$ is the random effect of cow $\mathrm{i}$ to correct for repeated measures within cow, and $\varepsilon_{\mathrm{ij}}$ is the residual 
error. A Šidák-corrected post hoc contrast test (with 9 simultaneous tests) was performed to compare pairwise the group means within each period. The results were presented as least squares means \pm standard error per period. The analyzed outcomes were assumed to be sufficiently normally distributed based on the graphical evaluation of the residuals of the model used (histogram and quantile-quantile plot). All statistical analyses were performed using the statistical software program R (version 3.3.1; www.r-project.org).

\section{RESULTS}

\section{DMI, Milk Production Performances, and Feed Efficiency}

Table 2 presents the least squares estimates of daily DMI, milk and FPCM production, milk composition, $\mathrm{N}$, and feed efficiency for each period (pretreatment, treatment, and washout) and each treatment group (REF, $\mathrm{NOP}_{\text {bas }}$, and $\left.\mathrm{NOP}_{\text {conc }}\right)$. Weekly least squares means for daily DMI and FPCM production are depicted in Supplemental Figure S1 (https://doi.org/10 $.3168 /$ jds.2018-14534). None of the above-mentioned variables were significantly different between groups in the 3 periods (Table 2), with the exception of the nitrogen and feed efficiency in the washout period. Nitrogen and feed efficiency for REF (28.9\% and 1.28 $\mathrm{kg}$ of $\mathrm{FPCM} / \mathrm{kg}$ of DMI, respectively) tended to be better than for both 3 -NOP groups, with $26.6 \%$ and $1.15 \mathrm{~kg}$ of $\mathrm{FPCM} / \mathrm{kg}$ of DMI for $\mathrm{NOP}_{\text {bas }}(P=0.07$ and $P=0.08$, respectively) and $27.9 \%$ and $1.25 \mathrm{~kg}$ of $\mathrm{FPCM} / \mathrm{kg}$ of DMI for $\mathrm{NOP}_{\text {conc }}(P=0.07$ and $P$ $=0.08$, respectively). The nitrogen and feed efficiency for $\mathrm{NOP}_{\text {bas }}$ were unexpectedly low due to a decline in milk production $(24.6 \mathrm{~kg}$ of $\mathrm{FPCM} / \mathrm{d})$ despite a similar DMI $(21.4 \mathrm{~kg}$ of DMI/d) compared with the end of the treatment period $(27.1 \mathrm{~kg}$ of $\mathrm{FPCM} / \mathrm{d}$ and $21.1 \mathrm{~kg}$ of DMI/d, wk 10; Supplemental Figure S1, https://doi .org/10.3168/jds.2018-14534).

\section{Additive Intake and Methane Emissions}

Throughout the treatment period the average daily intake of $3-\mathrm{NOP}$ was very similar for $\mathrm{NOP}_{\text {bas }}$ and $\mathrm{NOP}_{\text {conc }}$ (Supplemental Figure S2, https://doi.org/10.3168/jds .2018-14534). In both groups, fluctuations in the intake of 3-NOP occurred due to a fluctuating roughage intake. When averaged over the entire treatment period, the cows in $\mathrm{NOP}_{\text {bas }}$ received $1.52 \pm 0.02 \mathrm{~g}$ of $3-\mathrm{NOP} / \mathrm{d}$ and the cows in $\mathrm{NOP}_{\text {conc }}$ received $1.60 \pm 0.03 \mathrm{~g}$ of $3-\mathrm{NOP} / \mathrm{d}$, which matches very well with the desired dose of $1.60 \mathrm{~g} / \mathrm{d}$. We hypothesized that supplementing 3-NOP within a compound feed would be effective too, along with 3-NOP mixed in with the roughage, provided the compound feed was ingested frequently throughout the day. Further analysis of this daily frequency, based on dividing the day into twenty-four 1-h blocks, revealed that the cows of $\mathrm{NOP}_{\text {bas }}$ on average visited the feed bins (and ate the roughage with additive mixture) in ten 1-h blocks per 24-h period, with a median of $2.1 \mathrm{~h}$ between visits. Average minimum and maximum intake of the roughage with 3 -NOP in one 1-h block corresponded with 0.4 and $12 \%$ of the planned total 3 -NOP intake, respectively. On average, the cows of $\mathrm{NOP}_{\text {conc }}$ visited the concentrate feeder with the 3-NOP compound feed also in ten 1 -h blocks per 24 -h period, with a median of $2.4 \mathrm{~h}$ between visits. The minimum and maximum intake of the 3-NOP compound feed corresponded on average with 5 and $21 \%$ of the planned total $3-\mathrm{NOP}$ intake, respectively.

Figure 2 clearly shows that all groups had equal values for $\mathrm{CH}_{4}$ production $(\mathrm{g} / \mathrm{d})$ and $\mathrm{CH}_{4}$ yield $(\mathrm{g} / \mathrm{kg}$ of DMI) in the pretreatment period (wk 1 and 2), that these values for both 3 -NOP groups diverged from the reference group quite directly upon supplementation of the additive, and that the differences persisted over the entire treatment period. After treatment was stopped (washout), all values of the 3 -NOP groups returned toward the values of REF (Figure 2). In Table 3 the emission data per period and per group are given; like in Figure 2, it is clear that there were no differences between groups in the pretreatment period, that both 3 -NOP groups were different from REF in the treatment period but never different from each other, and that all groups did not differ in the washout period.

\section{DISCUSSION}

The present study showed that both methods of 3-NOP supplementation (i.e., mixed in with the roughage or incorporated in a concentrate pellet) are effective for reducing the enteric $\mathrm{CH}_{4}$ emissions of dairy cattle. Average methane yield reductions of 23 and $21 \%$ were achieved for $\mathrm{NOP}_{\text {bas }}$ and $\mathrm{NOP}_{\text {conc }}$, respectively, compared with REF. These percentages are in accordance with previous research in which a similar amount of 3-NOP was fed to dairy cattle in a TMR (Hristov et al., 2015; Lopes et al., 2016; Haisan et al., 2017). Furthermore, no negative effects on DMI, milk production, milk composition, and feed or nitrogen efficiency were found, in accordance with findings in other experiments on dairy cattle (Haisan et al., 2017). For both 3-NOP groups, $\mathrm{CH}_{4}$ mitigation was achieved from the moment they received 3-NOP until the end of the treatment period ( 8 wk later). Previous studies (Hristov et al., 2015; Romero-Perez et al., 2015) found no diminishing responses to the additive as time 
with 3-NOP supplementation proceeded. Our results confirmed this despite some variation in reduction percentages between treatment weeks. Those differences are probably related to combined fluctuations in DMI and 3-NOP intake.

Romero-Perez et al. (2015) suggested that the mode of supplementation is an important factor to consider when using 3-NOP. Thus, Hristov et al. (2015) concluded that $3-\mathrm{NOP}$ is effective in decreasing enteric $\mathrm{CH}_{4}$ emissions provided the additive is continuously present in the rumen, which is possible when it is mixed in a TMR and, hence, intake is spread throughout the day. However, cattle feeding strategies vary greatly between geographic areas and even between farms, and TMR is only one of many strategies used. The use of separate concentrate feeding in Western Europe allows farmers to manage their animals in one group with individually tailored concentrate feeding based on the cows' level of milk production. To date, no pelleted compound feed with 3-NOP has been tested for its effectiveness when used in separate concentrate feed stations. Therefore, 3 -NOP was incorporated in a pelleted compound feed in this experiment. We hypothesized that this new way of supplementing 3-NOP would be effective too, along with 3-NOP mixed in with the roughage, provided the compound feed was ingested frequently throughout the

Table 2. Least squares estimates of DMI, production of milk and fat- and protein-corrected milk (FPCM), milk composition (milk fat, milk protein, and MUN), N efficiency, and feed efficiency for groups REF, NOP ${ }_{\text {bas }}$, and $\mathrm{NOP}_{\text {conc }}$ in each period (pretreatment, treatment, and washout)

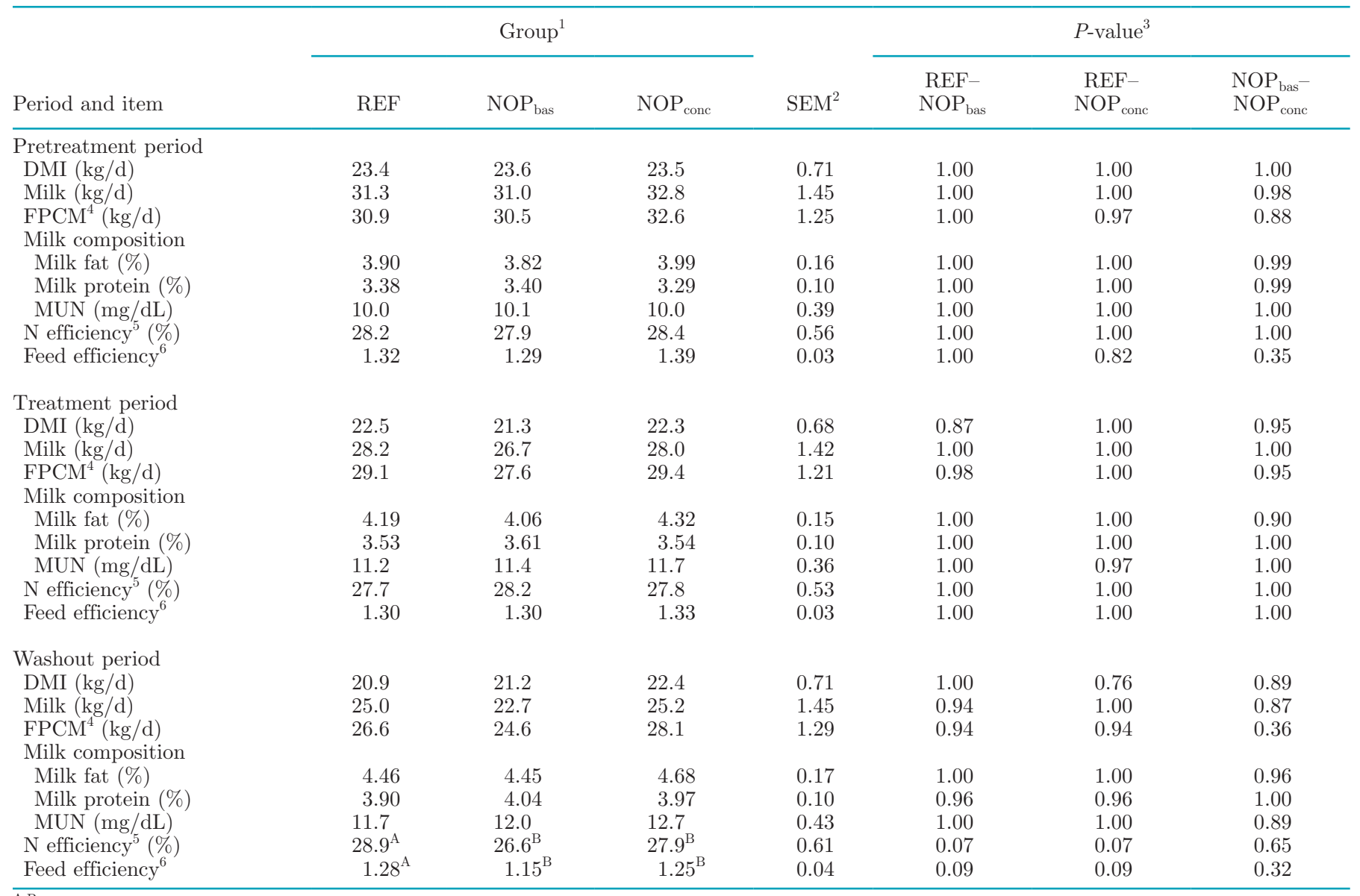

${ }_{\mathrm{A}, \mathrm{B}}$ Means within a row within a period with different superscripts tend to differ $(P<0.1)$.

${ }^{1} 3$-Nitrooxypropanol (3-NOP; DSM Nutritional Products, Basel, Switzerland) was provided in the treatment period only for the 3-NOP groups: $\mathrm{NOP}_{\text {bas }}(\mathrm{n}=10)$ and $\mathrm{NOP}_{\text {conc }}(\mathrm{n}=10)$. The cows in $\mathrm{NOP}_{\text {bas }}$ received $3-\mathrm{NOP}$ mixed in with the roughage $(1.6 \mathrm{~g} / \mathrm{cow}$ per day), and the cows in $\mathrm{NOP}_{\text {conc }}$ received 3-NOP incorporated in a concentrate pellet $(1.6 \mathrm{~g} / \mathrm{cow}$ per day). The reference group $(\mathrm{REF} ; \mathrm{n}=9)$ never received 3 -NOP.

${ }^{2}$ Largest SEM per period published in table.

${ }^{3} P$-values for the pairwise comparison between groups within period.

${ }^{4}$ Calculated as FPCM $=$ milk production $\times[0.337+(0.116 \times$ milk fat $\%)+(0.06 \times$ milk protein $\%)]$.

${ }^{5}$ Calculated as $\mathrm{N}$ efficiency $=[($ milk protein $/ 100) \times$ milk production $/ 6.37] /(\mathrm{CP}$ intake $/ 6.25)$.

${ }^{6}$ Calculated as feed efficiency $=\mathrm{kg}$ of $\mathrm{FPCM} / \mathrm{kg}$ of DMI. 


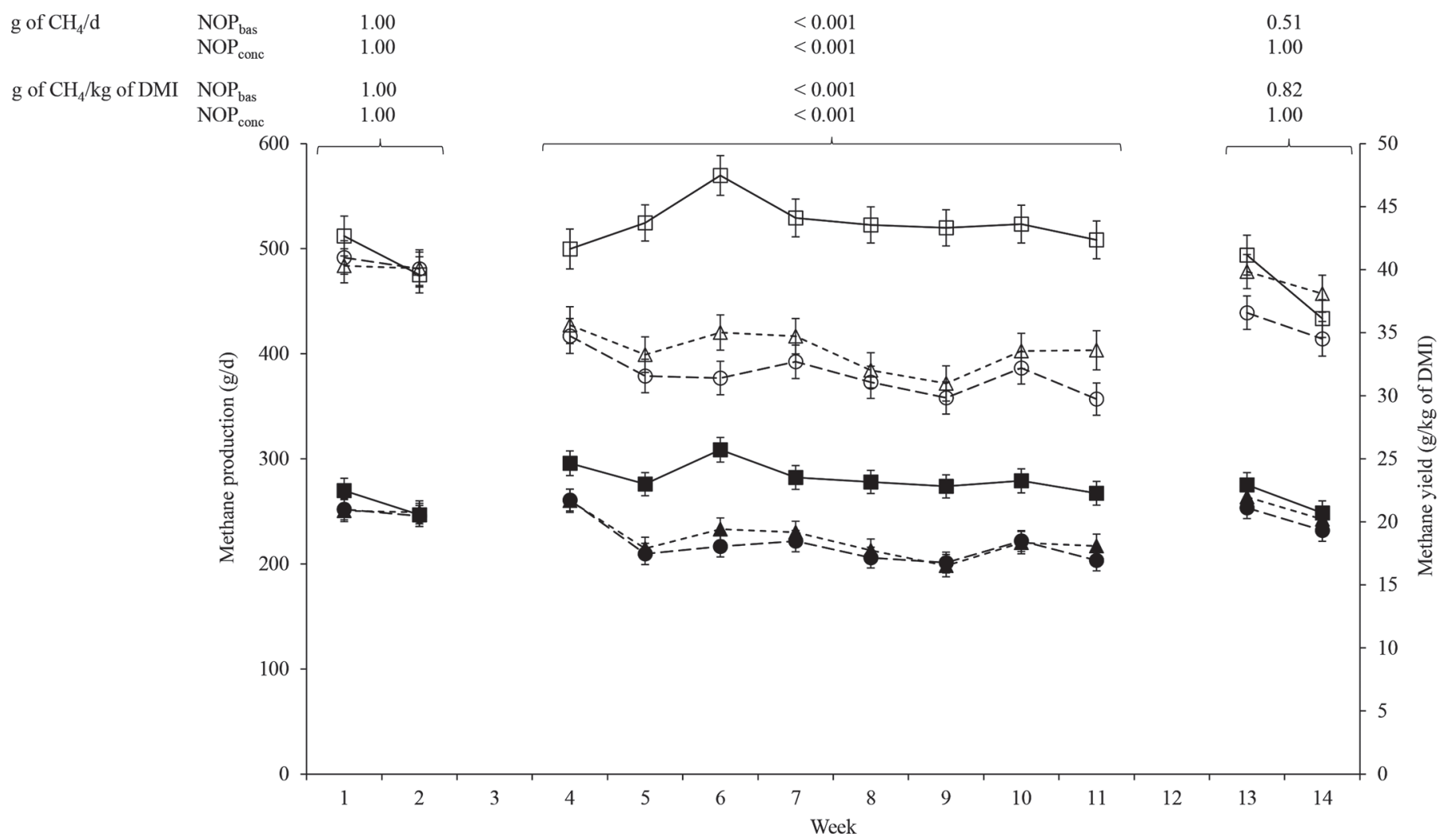

Figure 2. Methane $\left(\mathrm{CH}_{4}\right)$ production ( $\mathrm{g} / \mathrm{d}$; open symbols; left axis) and $\mathrm{CH}_{4}$ yield ( $\mathrm{g} / \mathrm{kg}$ of DMI; closed symbols; right axis) for all groups throughout the entire experimental period $(\mathrm{LSM} \pm \mathrm{SEM})$. Pretreatment period $=$ wk 1 to 2 ; treatment period $=$ wk 3 to 12 ; washout period = wk 13 to 14. Data from wk 3 and 12 were omitted. 3-Nitrooxypropanol (3-NOP) was provided in the treatment period only for the 3-NOP groups: $\mathrm{NOP}_{\text {bas }}(\mathrm{O} ; \mathrm{n}=10)$ and $\mathrm{NOP}_{\text {conc }}(\Delta ; \mathrm{n}=10)$. The cows in $\mathrm{NOP}_{\text {bas }}$ received 3 -NOP mixed in with the roughage $(1.6 \mathrm{~g} /$ cow per day), and the cows in $\mathrm{NOP}_{\text {conc }}$ received 3-NOP incorporated in a concentrate pellet $(1.6 \mathrm{~g} / \mathrm{cow}$ per day). The reference group (REF; $\square ; \mathrm{n}=9)$ never received 3-NOP. $P$-values (Šidák-corrected for 9 tests) for contrasts per period between REF and NOP bas or between REF and NOP conc are given at the top of the figure ( $\mathrm{NOP}_{\text {bas }}$ and $\mathrm{NOP}_{\text {conc }}$, respectively).

day. Indeed, both ways of supplementing 3 -NOP were effective in reducing the enteric $\mathrm{CH}_{4}$ emissions in this experiment. Moreover, we found no differences in $\mathrm{CH}_{4}$ reduction between these 2 strategies. Probably, the even distribution of 3-NOP intake throughout the day was a critical factor in this respect. Similarly, Reynolds et al. (2014) showed that dosing 3-NOP 2 times/d directly into the rumen had a transitory inhibitory effect on the $\mathrm{CH}_{4}$ emissions. Ingestion of the additive at more regular time intervals can probably compensate for this transitory effect, which is possibly caused by the fact that the additive is leaving the rumen with liquid outflow or through absorption or metabolism (Reynolds et al., 2014). Interestingly, in a screening trial with 3 -NOP, as part of a set of screening trials of different mitigation additives, we found only $11 \%$ reduction of the $\mathrm{CH}_{4}$ yield when 3-NOP was fed (D. Van Wesemael, unpublished data). In this trial, $1.7 \mathrm{~g}$ of $3-\mathrm{NOP} / \mathrm{cow}$ per day was top-dressed on the roughage 4 times/d. This intermittent intake of 3-NOP might have caused the intermediate reduction when compared with the present experiment (23 and $21 \%$ reduction for $\mathrm{NOP}_{\text {bas }}$ and $\mathrm{NOP}_{\text {conc }}$, respectively) and the study of Reynolds et al. (2014), where they saw only a $7 \%$ reduction when supplementing twice daily via the rumen cannula. When mixing into a TMR or incorporation into a pelleted compound feed is not possible, top-dressing can be another way to provide dairy cows with 3-NOP, although more research is needed to determine the effect on $\mathrm{CH}_{4}$ yield.

The $\mathrm{CH}_{4}$ mitigating effect of 3-NOP quickly disappeared after stopping the supplementation. Similar results were found with recovery periods of 2 to $3 \mathrm{wk}$ in beef cattle experiments (Romero-Perez et al., 2015; Vyas et al., 2016a). Such recovery or washout periods have not been described previously in earlier dairy cattle research into the effects of 3-NOP.

Future research should try to determine the minimal frequency of 3-NOP supplementation throughout the day in a wide range of dairy cattle diets. Haisan et al. 
(2017) suggested that the efficacy of 3-NOP can depend on the type of basal diet and probably is less effective in combination with high-roughage diets, as used in our experiment. The maximum temperature during pelleting in the current experiment was not greater than $70^{\circ} \mathrm{C}$. Future research is needed to confirm that pelleting with steam (at higher temperatures) is also not detrimental for the activity of 3-NOP. Although 3-NOP supplementation reduced $\mathrm{CH}_{4}$ emissions, no positive effect on cow performance was found. Adoption in practice is therefore unlikely unless economic benefits, legal requirements, or voluntary enticements could be developed to stimulate the use of this supplement (Hristov et al., 2013).

\section{CONCLUSIONS}

Feed supplementation with $3-\mathrm{NOP}$ is clearly a promising strategy for lowering enteric $\mathrm{CH}_{4}$ emissions of dairy cattle. Two methods of supplementation were tested: mixing 3-NOP into the roughage and incorporating 3-NOP into a pelleted compound feed. When supplemented pelleted feed with $3-\mathrm{NOP}$ is ingested with the same frequency as the supplemented roughage with 3-NOP, hardly any differences in $\mathrm{CH}_{4}$ emission reductions were observed between these 2 methods of supplementation. The 3 -NOP supplementation had no effect on milk production. The successful incorporation of 3-NOP into a pelleted compound feed in this experi-

Table 3. Least squares estimates of the emission data for the groups REF, $\mathrm{NOP}_{\mathrm{bas}}$, and $\mathrm{NOP}_{\text {conc }}$ in each period (pretreatment, treatment, and washout)

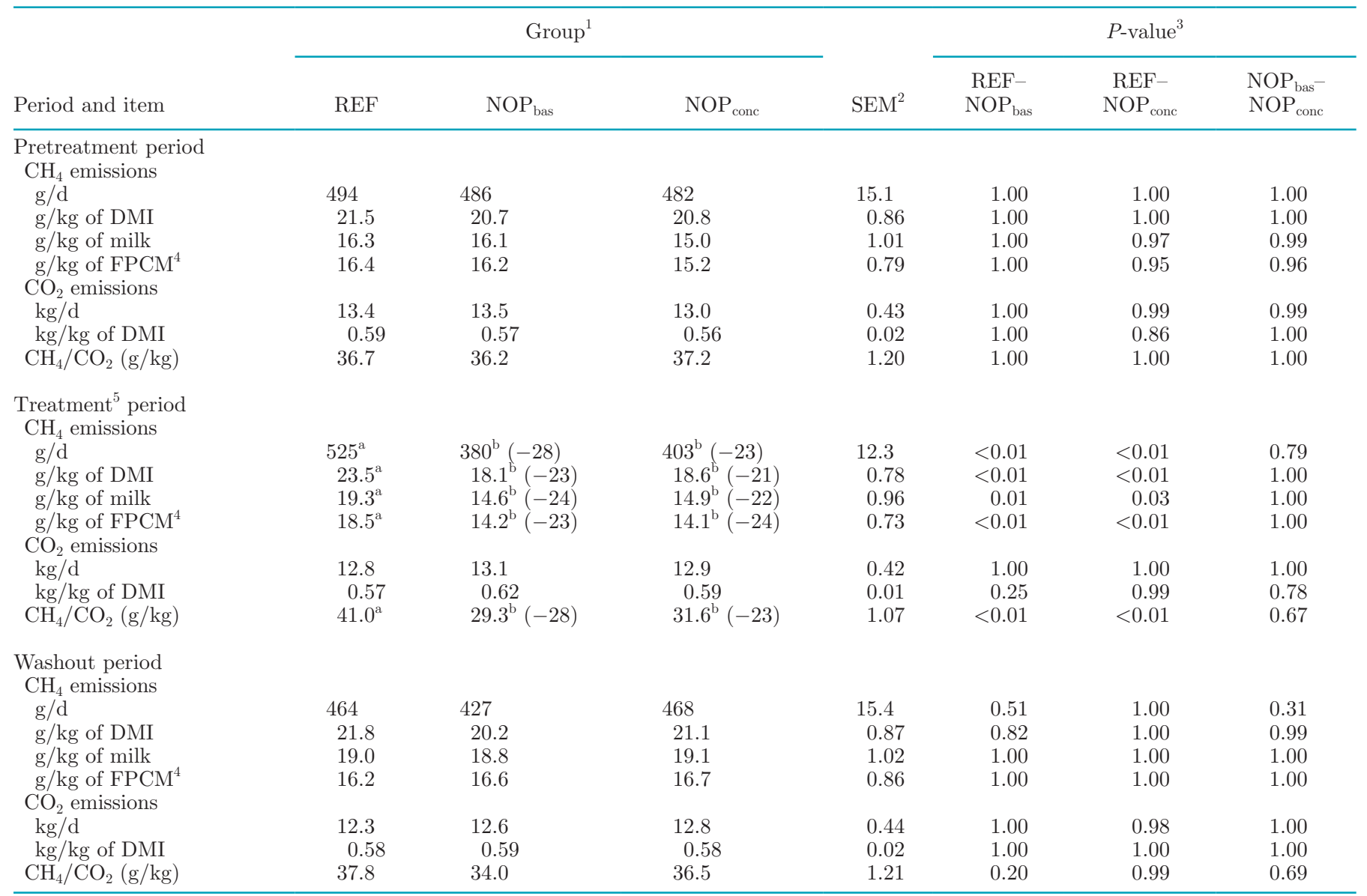

${ }^{\mathrm{a}, \mathrm{b}}$ Means within a row within a period with different superscripts differ $(P<0.05)$.

${ }^{1} 3$-Nitrooxypropanol (3-NOP; DSM Nutritional Products, Basel, Switzerland) was provided in the treatment period only for the 3-NOP groups: $\mathrm{NOP}_{\text {bas }}(\mathrm{n}=10)$ and $\mathrm{NOP}_{\text {conc }}(\mathrm{n}=10)$. The cows in $\mathrm{NOP}_{\text {bas }}$ received $3-\mathrm{NOP}$ mixed with the roughage $(1.6 \mathrm{~g} / \mathrm{cow}$ per day), and the cows in $\mathrm{NOP}_{\text {conc }}$ received 3-NOP incorporated in a concentrate pellet $(1.6 \mathrm{~g} / \mathrm{cow}$ per day). The reference group (REF; $\mathrm{n}=9) \mathrm{never}$ received 3-NOP.

${ }^{2}$ Largest SEM per period published in table.

${ }^{3} P$-values for the pairwise comparison between groups within period.

${ }^{4}$ Fat- and protein-corrected milk $(\mathrm{FPCM})=$ milk production $\times[0.337+(0.116 \times$ milk fat $\%)+(0.06 \times$ milk protein $\%)]$.

${ }^{5}$ When significant, percentage (\%) differences compared with REF are given in parentheses. 
ment can be an important step toward commercial introduction of the product in the dairy sector of Western Europe.

\section{ACKNOWLEDGMENTS}

This research was funded by the government agency Flanders Innovation and Entrepreneurship (VLAIO, former IWT; Belgium; LA135081) and by DSM Nutritional Products (Basel, Switzerland). This work was further supported by an STSM grant from the COST action FA1302 (www.methagene.eu). Thanks to the staff of the ILVO (Flanders Research Institute for Agriculture, Fisheries and Food, Melle, Belgium) dairy farm for taking care of the animals, in particular the people who milked and fed the cows, the people of the feed mill, and those responsible for the overall functioning of the farm. Special thanks to Stefan Meirlaen, Michaël De Guchtenaere, Sara Van Lembergen, Jorne Brouckaert, Thijs De Mulder, and Karen Goossens (all of ILVO, Melle, Belgium) for their practical help during the experiments. Thanks also to the ILVO Animalab laboratory for all feed and milk analyses. The authors also thank Miriam Levenson (ILVO, Merelbeke, Belgium) for the English language review of this paper. Stéphane Duval and Maik Kindermann are employees of DSM Nutritional Products (Basel, Switzerland).

\section{REFERENCES}

De Boever, J. L., K. Goossens, N. Peiren, J. Swanckaert, B. Ampe, D. Reheul, D. L. De Brabander, S. De Campeneere, and L. Vandaele. 2017. The effect of maize silage type on the performances and methane emission of dairy cattle. J. Anim. Physiol. Anim. Nutr. (Berl.) 101:e246-e256. https://doi.org/10.1111/jpn.12598.

Duin, E. C., T. Wagner, S. Shima, D. Prakash, B. Cronin, D. R. Yáñez-Ruiz, S. Duval, R. Rümbeli, R. T. Stemmler, R. K. Thauer, and M. Kindermann. 2016. Mode of action uncovered for the specific reduction of methane emissions from ruminants by the small molecule 3-nitrooxypropanol. Proc. Natl. Acad. Sci. USA 113:6172-6177. https://doi.org/10.1073/pnas.1600298113.

Duval, S., and M. Kindermann. 2012. Use of nitrooxy organic molecules in feed for reducing methane emission in ruminants, and/ or to improve ruminant performance. World Intellectual Property Organization, assignee. Pat. No. WO 2012/084629 A1.

Ermler, U., W. Grabarse, S. Shima, M. Goubeaud, and R. K. Thauer. 1997. Crystal structure of methyl-coenzyme M reductase: The key enzyme of biological methane formation. Science 278:1457-1462. https://doi.org/10.1126/science.278.5342.1457.

Haisan, J., Y. Sun, L. Guan, K. A. Beauchemin, A. Iwaasa, S. Duval, M. Kindermann, D. R. Barreda, and M. Oba. 2017. The effects of feeding 3-nitrooxypropanol at two doses on milk production, rumen fermentation, plasma metabolites, nutrient digestibility, and methane emissions in lactating Holstein cows. Anim. Prod. Sci. 57:282-289. https://doi.org/10.1071/an15219.

Haisan, J., Y. Sun, L. L. Guan, K. A. Beauchemin, A. Iwaasa, S. Duval, D. R. Barreda, and M. Oba. 2014. The effects of feeding 3-ni- trooxypropanol on methane emissions and productivity of Holstein cows in mid lactation. J. Dairy Sci. 97:3110-3119. https://doi.org/ 10.3168/jds.2013-7834

Hammond, K. J., D. J. Humphries, L. A. Crompton, C. Green, and C. K. Reynolds. 2015. Methane emissions from cattle: Estimates from short-term measurements using a GreenFeed system compared with measurements obtained using respiration chambers or sulphur hexafluoride tracer. Anim. Feed Sci. Technol. 203:41-52. https://doi.org/10.1016/j.anifeedsci.2015.02.008.

Hristov, A. N., J. Oh, F. Giallongo, T. W. Frederick, M. T. Harper, H. L. Weeks, A. F. Branco, P. J. Moate, M. H. Deighton, S. R. Williams, M. Kindermann, and S. Duval. 2015. An inhibitor persistently decreased enteric methane emission from dairy cows with no negative effect on milk production. Proc. Natl. Acad. Sci. USA 112:10663-10668. https://doi.org/10.1073/pnas.1504124112.

Hristov, A. N., J. Oh, C. Lee, R. Meinen, F. Montes, T. Ott, J. Firkins, A. Rotz, C. Dell, A. Adesogan, W. Yang, J. Tricarico, E. Kebreab, G. Waghorn, J. Dijkstra, and S. Oosting. 2013. Mitigation of greenhouse gas emissions in livestock production- $\mathrm{A}$ review of technical options for non- $\mathrm{CO}_{2}$ emissions. FAO Animal Production and Health paper no. 177. P. J. Gerber, B. Henderson, and H. P. S. Makkar, ed. FAO, Rome, Italy.

Huhtanen, P., E. H. Cabezas-Garcia, S. Utsumi, and S. Zimmerman. 2015. Comparison of methods to determine methane emissions from dairy cows in farm conditions. J. Dairy Sci. 98:3394-3409. https://doi.org/10.3168/jds.2014-9118.

Lopes, J. C., L. F. de Matos, M. T. Harper, F. Giallongo, J. Oh, D. Gruen, S. Ono, M. Kindermann, S. Duval, and A. N. Hristov. 2016. Effect of 3-nitrooxypropanol on methane and hydrogen emissions, methane isotopic signature, and ruminal fermentation in dairy cows. J. Dairy Sci. 99:5335-5344. https://doi.org/10.3168/jds.2015 $-10832$

Martínez-Fernández, G., L. Abecia, A. Arco, G. Cantalapiedra-Hijar, A. I. Martín-García, E. Molina-Alcaide, M. Kindermann, S. Duval, and D. R. Yáñez-Ruiz. 2014. Effects of ethyl-3-nitrooxy propionate and 3-nitrooxypropanol on ruminal fermentation, microbial abundance, and methane emissions in sheep. J. Dairy Sci. 97:37903799. https://doi.org/10.3168/jds.2013-7398.

Reynolds, C. K., D. J. Humphries, P. Kirton, M. Kindermann, S. Duval, and W. Steinberg. 2014. Effects of 3-nitrooxypropanol on methane emission, digestion, and energy and nitrogen balance of lactating dairy cows. J. Dairy Sci. 97:3777-3789. https://doi.org/ 10.3168/jds.2013-7397.

Romero-Perez, A., E. K. Okine, S. M. McGinn, L. L. Guan, M. Oba, S. M. Duval, M. Kindermann, and K. A. Beauchemin. 2015. Sustained reduction in methane production from long-term addition of 3-nitrooxypropanol to a beef cattle diet. J. Anim. Sci. 93:17801791. https://doi.org/10.2527/jas.2014-8726.

Tamminga, S., W. M. Van Straalen, A. P. J. Subnel, R. G. M. Meijer, A. Steg, C. J. G. Wever, and M. C. Blok. 1994. The Dutch protein evaluation system: The DVE/OEB-system. Livest. Prod. Sci. 40:139-155.

Van Es, A. J. H. 1978. Feed evaluation for ruminants. I. The systems in use from May 1977 onwards in the Netherlands. Livest. Prod. Sci. 5:331-345.

Vyas, D., S. M. McGinn, S. M. Duval, M. K. Kindermann, and K. A. Beauchemin. 2016a. Effects of sustained reduction of enteric methane emissions with dietary supplementation of 3-nitrooxypropanol on growth performance of growing and finishing beef cattle. J. Anim. Sci. 94:2024-2034. https://doi.org/10.2527/jas.2015-0268.

Vyas, D., S. M. McGinn, S. M. Duval, M. K. Kindermann, and K. A. Beauchemin. 2016b. Optimal dose of 3-nitrooxypropanol for decreasing enteric methane emissions from beef cattle fed high-forage and high-grain diets. Anim. Prod. Sci. 58:1049-1055. https://doi .org/10.1071/an15705. 